\title{
Питання психології
}

УДК 316:159.922.63

DOI: $10.33099 / 2617-6858-21-64-4-38-48$

Воронова О. Ю. кандидат психологічних наук, стариий викладач кафедри психологї Мукачівський державний університет https://orcid.org/0000-0002-6504-240X

Барчій М. С. стариий викладач кафедри психологї Мукачівський держсавний університет https://orcid.org/0000-0002-7762-0959

\section{ОКРЕМІ СОЦАЛЬНО-ПСИХОЛОГІЧНІ ПРОБЛЕМИ СТАРІННЯ}

У статті проаналізовано погляди вітчизняних та зарубіжних науковиів на соиіально-психологічні проблеми старіння. Висвітлено психологічні особливості людей похилого віку. Розглянуто основні підходи до вивчення старості та старіння; проблему ейджизму та чинники виходу на пенсію; питання активного старіння та передпенсійної підготовки. Виокремлено чинники, які впливають на адаптачійні процеси людини похилого віку до нової якості життя.

Ключові слова: старість; старіння; геронтологія; люди похилого віку; криза старості; соціальна aдаптаиія.

Вступ. Постійне зростання частки осіб похилого віку в структурі країн світу стає впливовою соціально-демографічною тенденцією практично всіх розвинутих країн. Збільшення тривалості життя призводить до суттєвих змін в усіх соціальних інститутах та вимагає вирішення відповідних проблем: економічних (пенсійне забезпечення), політичних (збільшення частки людей старшого віку), сімейних (догляд за старими родичами), культурно-дозвіллєвих (створення умов для культурного відпочинку людей похилого віку), інформаційно-комунікативних (питання ейджизму та геронтофобії).

Демографічна ситуація в Україні аналогічна світовим тенденціям i характеризується стійким процесом старіння населення. 3 урахуванням поточних демографічних процесів i прогнозів їх розвитку підвищується роль та змінюється статус літніх людей в державі й суспільстві, що вимагає створення умов для підвищення рівня життя осіб старшого віку, посилення соціальної та психологічної підтримки, забезпечення доступності та підвищення якості соціальних і психологічних послуг, надання літнім людям максимально широких можливостей для комфортного проживання й активного довголіття.
Розгляд проблем літньої людини $\epsilon$ надзвичайно актуальним, оскільки їх вирішення не тільки визначає активність літньої людини та іiі позицію в житті суспільства, а й дає можливості для адаптації людей похилого віку до нової соціальної ситуації i зміну ставлення до них у суспільстві.

Мета статті - здійснити теоретичний аналіз соціально-психологічних проблем старіння на сучасному етапі.

Теоретичне підгрунтя. Психологічні особливості осіб похилого віку досліджувалися М. Александровою, Б. Ананьєвим та ін. в контексті вивчення закономірностей психічного розвитку, періодизацією старості займалися О. Лідерс, В. Моргун, М. Пряжніков та ін. Психологічні механізми старіння розглядали В. Безруков, Т. Марцинковська, В. Фролькіс та ін. М. Смульсон досліджувала механізми, умови позитивного розвитку особистості, новоутворення людей літнього віку. Різні типи розвитку особистості в похилому віці описали Д. Бромлей, Л. Анциферова, І. Кон. Особистісні якості літніх людей розглядали О. Березіна, I. Грошев, М. Срмолаєва та ін. Духовний розвиток літніх людей досліджували І. Бех, Т. Джонсон, Е. Помиткін. Деякі питання життєвого шляху літніх осіб 


\section{Питання психології}

відображено в роботах О. Бондарчук, Т. Титаренко. Творчий потенціал особистості в пізній дорослості проаналізовано в дослідженнях Л. Міщихи. В психології доволі широко окреслена проблематика старіння, яка, проте, ще не в повній мірі систематизована. Збільшення тривалості життя приводить до збільшення періоду життя в зовсім інших соціальних, психологічних, економічних умовах.

Методи дослідження. У процесі дослідження використано теоретичний аналіз та узагальнення науково-теоретичних та методичних джерел 3 проблем психології старості.

Результати і обговорення. Вікова група людей похилого віку $\epsilon$ унікальною соціальною групою, яка має біопсихічні, соціопсихічні, соціокультурні та міжособистісні особливості. Старіння розглядається як закономірний та нерівномірний процес фізіологічних, психологічних, соціальних змін, які носять індивідуальний характер та потребує комплексного вивчення.

Міждисциплінарний розгляд старіння передбачає, що воно $є$ динамічним процесом, що задається як об'єктивно біологічними характеристиками, суспільними обставинами соціального життя суб'єкта (ця характеристика, попри зовнішню заданість, $€$ мінливою навіть у межах одного суспільства. Представники одних професій можуть виходити на пенсію в більш ранньому віці (військові, спортсмени), аніж інших), так i суб'єктивними характеристиками, що грунтуються на власній інтерпретації суб'єктом соціального світу та відповідній самоідентифікації. Виділяють такі різновиди старості:

хронологічну - пов'язану 3 кількістю прожитих років. Вона визначається паспортним віком та важлива 3 позиції юриспруденції, демографії, економіки;

$\checkmark \quad$ фізіологічну - пов'язану зі станом здоров'я та наявністю хронічних захворювань;

$\checkmark \quad$ психологічну - пов'язану 3 суб'єктивним самовизначенням людиною себе як старої, відчуттям власного біологічного віку; соціальну - вона поєднує усі попередні різновиди у реальних соціальних практиках суб'єктів. Остання орієнтується на такий критерій, як адаптаційна здатність[8].

Старіння притаманне всім людям, але особливості його перебігу залежить від ряду чинників, зокрема, - генетичних, умов навколишнього середовища (екології, харчування), соціокультурних (доступу до медичних препаратів та можливості підтримувати рівень здоров'я) тощо. Біологічне старіння виявляється у доволі тісному зв'язку 3 соціокультурними та соціоструктурними умовами проживання, наприклад, харчовими системами (національною кухнею), що сприяють виникненню вікових захворювань певного профілю, тривалістю і специфікою праці, що може призвести до пришвидшеного старіння організму тощо.

Виділяють декілька основних наукових напрямів, що вивчають старіння. Найперше, геронтологія та медицина - у цих межах досліджується специфіка біологічного старіння та генетичних передумов старіння, в тому числі патологічного старіння (наприклад, такого захворювання, як прогерія - пришвидшеного старіння організму), а також захворювань, що є специфічними для старшого віку, наприклад, старечої деменції, хвороби Альцгеймера, хвороби Паркінсона.

Демографічний напрям зосереджується на вивченні даних про вікову структуру населення, динаміку народжуваності, смертності, середньої тривалості життя. Юридичний - виділенні вікових меж для подальшого правового регулювання взаємодії між представниками різновікових груп між собою та державою. Економічний - тісно пов'язаний з юридичним, проте в його основі лежить економічна рентабельність віднесення людей до певної вікової групи та вирахування міри економічного навантаження економічно «пасивної» до «активної» частини населення. В основі психологічного та соціальнопсихологічного напрямів лежить дослідження щодо динаміки самоіндентифікації та 


\section{Питання психології}

психологічного самопочуття людей різного віку, відповідно - зміни у їх поведінці, стосунках $з$ оточуючими, бажань та потреб тощо. Уявлення про старіння i його межі змінюються не лише в рамках галузей знань, а й залежно від «регіональної» специфіки науки, маючи прямий зв'язок 3 рівнем економічного розвитку суспільства, державним устроєм та відповідними програмами соціального страхування, демографічними характеристиками (тривалістю життя та специфікою відтворення суспільства) тощо.

У психології старість розглядається як заключний період життя, умовний початок якого пов'язаний 3 відходом від безпосередньої участі в продуктивному житті суспільства. Виокремлюються наступні підходи розгляду старіння:

- екзистенційна теорія;

- психоаналітична теорія;

- теорія інтенційності;

- теорія розвитку.

У межах екзистенційної психології старіння розглядається як сприятливий та природний період життя. Так, з цієї позиції К. Ясперс вважав, що в старості можливості згасають, проте їх замінює багатство накопиченого досвіду, тож старості не слід боятися - в неї є свої переваги. Стара людина більш скована тілесно, проте більш вільна духовно. Паралельно процесам старіння відбуваються й активні процеси, що не сковуються біологічними процесами і здатні тривати до глибокої старості. Можна визнати доречність такого підходу, однак він, поперше, не визначає чітко вікові межі старості, по-друге, суперечить соціальним практикам: чомусь ніхто не поспішає старіти, навпаки, збереження сил і здоров'я проголошується в розвинених країнах ледве не культом.

Інший напрям - психоаналітичний. Серед найяскравіших представників цього напряму, які у своїх працях зачіпали проблематику старіння - К. Юнг та А. Адлер. Зокрема, К. Юнг великого значення надавав вивченню проблем «другої половини життя людини». Він вважав, що середина життя - поворотний момент до відкриття нових можливостей саморозвитку, адже людина уже не потребує встановлення нових зовнішніх зв'язків і може зайнятися внутрішньою роботою самопізнання - «індивідуацією». У старості потреба вироблення цілісного погляду на власне життя, самоспостереження виступає на передні позиції та пов'язана 3 віднаходженням стійкої психічної і моральної рівноваги. Важливе і переконання К. Юнга в тому, що кінцевий період життя людини наділений власним значенням i не $\epsilon$ «придатком» до попередніх етапів життя. Вчений також піднімав питання підготовки до старості, вважаючи, що основним чинником нервових зривів і незадоволеності в старшому віці є непідготовленість до нього [11].

А. Адлер вважав, що однією 3 основних спонук діяльності $є$ почуття неповноцінності, яке людина прагне компенсувати протягом життя. У старшому віці це почуття загострюється через зниження фізичних i фізіологічних можливостей, що унеможливлюють ведення попереднього способу життя. Адлерівська концепція щодо діалектичного перетворення органічної недостатності через суб'єктивне почуття неповноцінності в психічне прагнення до компенсації, може бути застосована i до старості. 3 цього приводу Л. Виготський, зазначав, що прагнення до компенсації дефекту породжується не стільки внутрішніми спонуками, скільки зовнішніми - соціальними. Тобто компенсація набуває соціального характеру, відіграє роль своєрідного «соціального протезу»[2].

Найбільший внесок у розвиток психологічної конщепції старості зробив Е. Еріксон, представник психології розвитку. Він вважав, що протягом життя особистість проходить вісім стадій розвитку, на кожній 3 яких вона повинна виконати специфічні для конкретного віку завдання. Їх виконання веде до набуття нових психологічних якостей i переходу на наступну «сходинку» розвитку. При цьому саме восьмою «сходинкою» $\epsilon$ старість. Остання набута якість - нова форма его-ідентичності та досягнення гармонії, відчуття самототожності. На протилежній 


\section{Питання психології}

стороні шкали лежить розчарування в прожитому житті, відчуття відчаю та страху смерті. Поряд із тим, концепція Е. Еріксона $\epsilon$ певним епігенетичним шаблоном, у якому уніфікуються послідовні стадії розвитку тривіальної особистості. Застерігаючи від порушень проходження окремих етапів життя, вона має певний позитивний терапевтичний ефект, однак недооцінює конструктивну силу конфліктів і внутрішніх суперечностей у процесі самоактуалізації особистості. Зокрема, восьма стадія розвитку людини, за Е. Еріксоном, тобто старість, характеризується втратою особистісного потенціалу й заміщенням його потенціалом молодшого покоління. Характерне для цього періоду самовизначення в межах континууму «цілісність-безнадійність» $є$ своєрідним психологічним перебуванням між раєм «виконаності себе» і пеклом «нікчемності прожитого життя». Цим фактично позбавляються права на реалізацію соціального потенціалу ті, чиє життя не було послідовною лінією проходження попередніх стадій розвитку особистості.

Значення компенсаторних можливостей у старшому віці відображено в працях 3 психології розвитку. 3 позиції закону метаморфози Л. Виготського, старіння може розглядатися не лише крізь призму зниження можливостей, а й з позицій якісних психічних змін, передусім психічного розвитку, набуття нових якостей. П. Балтес встановив, що люди похилого віку здатні підтримувати на високому рівні деякі когнітивні функції, незважаючи на зниження інших — це відбувається через підключення інших когнітивних ресурсів, не зачеплених процесом старіння. Він назвав такий процес «селективною оптимізацією 3 компенсацією» [3]. Подібно до того, як у незрячих людей відбувається компенсація за рахунок посилення можливостей інших рецепторів, так і в старших людей спостерігається така когнітивна компенсація.

О. Краснова описує старіння як закономірний та гетерохронний процес вікових змін, який діє на всіх рівнях організму. Разом $з$ тим, на думку авторки, ослаблення гомеостатичних процесів викликає появу механізмів пристосування до нових умов життя. Засобами компенсації емоційного напруження, підвищення рівня соціально-психологічної адаптації можуть бути спілкування 3 природою, самостійна творчість, хобі, поява нової діяльності, інтересів, перспектив, спілкування 3 хатніми тваринами, догляд за рослинами, городом, садибою, захоплення мистецтвом.

Особливістю психіки людини похилого віку є те, що інтеріоризація (знань, культури, правил і норм суспільства) у старості вже майже не має колишнього значення. Сформувати нові знання дуже важко, ще складніше наповнювати їх емоційними переживаннями для формування нових мотивів. Внаслідок цього у літніх людей виникають проблеми 3 формуванням нових соціальних ролей, їм важче звикати до нових цінностей, індикатором для порівняння, зазвичай, виступає минуле, а все нове часто, внаслідок нерозуміння, може викликати негативну реакцію. Ускладнюється соціальна ідентифікація, тому в похилому віці складно адаптуватися до нового середовища (соціального, культурного, екологічного), що, в свою чергу, часто призводить до особистісного відчуження, соціальної ізоляції.

Згідно з положеннями, які розглядає О. Хухлаєва, перед людиною похилого віку в кризовий період стоять наступні завдання, поперше, прийняти те, що життя має свій кінець, по-друге, змиритися 3 неможливістю виконання життєвих завдань попередніх вікових періодів.

Віковий період осіб похилого віку визначається переоцінкою цінностей, підсумком прожитих років, випробуванням себе в нових видах діяльності. Особи на цьому віковому етапі вирішують важкі завдання, насамперед, внаслідок погіршення здоров'я людина похилого віку стає залежною від інших людей, що викликає не тільки фізичні, а також психологічні проблеми. Криза пенсійного віку - це стадія вибору стратегії подальшого життя. Позитивна стратегія надає індивіду можливість формування нових соціальних зв'язків, 


\section{Питання психології}

негативна - налаштована на фізичне виживання.

Ідея безперервного розвитку впроваджена у роботах M. Шахматова. Спираючись на запропоновані П. Балтесом три напрямки вікового розвитку: нормативний віковий розвиток (біологічне та соціальне (вихід на пенсію) старіння), нормативний історичний розвиток (зв'язок індивідуального розвитку 3 соціальноісторичними подіями), ненормативний історичний розвиток (вплив особливих подій, які існують в житті кожної людини), М. Шахматов зазначає, що розвиток людини триває протягом всього життєвого шляху та залежить від злагодженої взаємодії внутрішнього та зовнішнього середовища. Нормальними проявами старіння $є$ ті випадки, коли у старості не відбувається яких-небудь змін характеру й до кінця життя літні залишаються тими самими людьми, якими були й раніше. Спираючись на власний досвід досліджень, автор доходить висновку, що у старості не відбувається якої-небудь зміни особистісних характеристик, ні моральні, ні соціальні якості особистості не втрачаються. Якщо ж зміни відбуваються, то вони зумовлені розвитком негативних вікових органічних процесів, які мають відношення до функціонування центральної нервової системи. Акцентуація рис характеру, а також i негативні зміни особистості у старості, що вперше виявляються, є симптомами власне вікових психозів пізнього віку. Крім цього все, що становить індивідуальність людини, іiі особисту та соціальну цінність і значущість, не змінюється у старості [5].

На основі аналізу робіт різних авторів встановлено, що у цей віковий період особливого значення набуває спілкування, як один із чинників успішної адаптації та збереження вміння взаємодії між людьми. У зв'язку 3 тим, що соціальні контакти зменшуються, людина похилого віку втрачає навички спілкування, тому спілкування в родині виконує багато функцій, насамперед, це розвиток «Я» особи похилого віку як члена родини, розвиток мотиваційної сфери в подружніх стосунках, стосунках 3 дітьми та онуками, стосунках з братами та сестрами. Спілкування 3 онуками має не тільки позитивний емоційний вплив, а також надає людині похилого віку нового соціального статусу бабусь та дідусів. Дружні відносини, спільні інтереси 3 іншими людьми компенсують в цей віковий період почуття самотності, непотрібності.

Комплексне дослідження особливостей міжособистісного спілкування осіб похилого віку проведено О. Коваленко. На думку авторки, міжособистісне спілкування осіб похилого віку відіграє важливу роль у комунікативній підсистемі психіки особистості та вирішує такі завдання, як формування та корегування смислу життя, регулювання емоційних станів і переживань, допомагає будувати відносини та конструктивні способи взаємодії 3 іншими людьми. Визначаючи спілкування як основний вид діяльності людей похилого віку, О. Коваленко наголошує, що особи похилого віку $€$ суб'єктами міжособистісного спілкування і свідомої діяльності [6].

3 метою адаптації осіб похилого віку до нових умов та нових соціальних ролей необхідним і важливим $є$ розвиток системи їхньої соціально-психологічної підтримки (відповідних соціальних клубів, геронтопсихологічних центрів, територіальних центрів соціального обслуговування). На державному рівні в нашій країні це реалізовано через діяльність Територіальних центрів соціального обслуговування (надання соціальних послуг) та роботу профільних громадських організацій. Основною сферою діяльності вищеназваних закладів $€$ організація та забезпечення адекватного рівня соціального життя людей похилого віку, забезпечення їх дозвілля, навчання та розвитку. Однак поширеність і забезпеченість даних закладів та організацій $\epsilon$ недостатньою. Для подолання даної ситуації потрібна діяльна соціальна включеність та активність власне людей похилого віку за підтримки всіх ланок державного та суспільного апарату, які тим чи іншим чином можуть сприяти вирішенню проблем людей похилого віку. По-перше, 


\section{Питання психології}

необхідно поліпшити інформаційне забезпечення: в ЗМІ повинен формуватися образ «позитивної старості» [1]. По-друге, перспективними $€$ ідеї організації участі літніх людей у суспільно-корисній діяльності та реалізації їхніх власних прагнень до суспільного виробництва (В. Моргун): робота на виробництві 3 неповним робочим днем (із збереженням пенсії), робота вдома, робота на громадських засадах за місцем проживання, в публічних бібліотеках, наставництво i передача досвіду молоді, керівництво гуртками для дітей та ін. [7].

Будь-яке 3 перерахованих вище занять може відрізнятися від того, що робили люди похилого віку в минулому, і вимагатиме від них істотної перебудови свого способу життя, набуття нових знань, вмінь і навичок. Люди похилого віку використовують структуру свого досвіду, витягуючи з неї елементи, щоб підтримувати існуючі можливості на належному рівні і перетворювати їх в нові можливості. Деякі особистісні характеристики, сформовані в попередній діяльності, зберігаються в літньому віці, сприяючи адаптації до нової ситуації ситуації подальшого старіння. Причому адаптація здійснюється через пошук умов, що підтримують орієнтацію, інтереси, спрямованість та звички людини похилого віку, що склалися впродовж життя, за рахунок використання накопиченого досвіду [8].

Характеризуючи високий рівень задоволеності і, відповідно, адаптації людини в старості, Т. Волкова використовує поняття «психологічний комфорт» [4]. Це одна 3 головних умов благополучної старості, i сутність ії полягає в тому, що літня людина відчуває почуття задоволення від прожитого життя, почуття власної необхідності і незамінності, принаймні для близьких, захист від негативних подій зовнішнього світу, приниження, упереджень і підозр 3 боку інших. Зниження здатності людини похилого віку адаптуватися до різних змін призводить до негативних наслідків, у неї знижуються життєвий тонус, ініціативність і прагнення до активності (проявляється в обережності до нового, до різних змін).
Втрата глибоких, сутнісних соціальних зв'язків, відсутність перспективи у цьому віці, що проявляється у зниженні поведінкового контролю та «виснаженні» чутливості, призводить до зростання егоцентричності у старості, переконаності людей похилого віку в беззаперечній справедливості та виправданості зайнятої ними позиції [5]. Це явище можна прослідкувати через викривлену інтерпретацію оточення, воно проявляється у таких рисах, як амбітність, образливість, нетерпимість до заперечень. Втрата соціальних зв'язків може провокувати розвиток, так званої, старечої балакучості та загострення особистісних рис.

Зокрема літнім людям притаманна особлива стурбованість життям, подіями у суспільстві, майбутнім, родичами. Цей, здебільшого, не досить усвідомлений стан за своїм проявом нагадує незначну тривогу. Такий стан стурбованості, зумовлений власне старінням, і супроводжується зменшенням психічної сили, збідненням змісту психічного життя, більш економним використанням психічних ресурсів[5].

Припинення трудової діяльності зумовлює підвищення тривожності, погіршення самопочуття i певне падіння соціального статусу. Якщо літня людина, вийшовши на пенсію, не налагодить нових аспектів для застосування своїх сил, то відбувається поступове звуження кола інтересів, зосередження на своєму внутрішньому світі, зниження здатності до спілкування; все це призводить до емоційної кризи. Через зниження емоційного забарвлення у спілкуванні, посилюється роль стереотипів i навичок спілкування, накопичених в життєвому досвіді, що веде до стандартизації спілкування в звичайних умовах. Щоб цього не сталося, літній людині необхідно робити зусилля над собою, не давати волі негативним емоціям, брати відповідальність за своє життя і свій стан на себе, а не перекладати іï на рідних і близьких, прагнути самій шукати нові інтереси i проявляти себе в новій якості, нових ролях.

Упереджене ставлення до людей похилого віку створюють соціальні інститути, 


\section{Питання психології}

особливо 3MI, культивуючи негативні стереотипи старіння та віку. Західні культури орієнтовані на молодь. Пряма дискримінація починається тоді, коли працівники старшого віку стають менш конкурентними на ринку праці. Дискримінація виявляється в просуванні кар'єрними сходами; відносно розвитку компетентності через навчання новим технологіям: старшим пропонують менше можливостей для навчання, і вони, у свою чергу, також менше цікавляться цим, на відміну від молодих працівників. У сучасному суспільстві набув поширення ейджизм як дискримінація за віковою ознакою. Люди похилого віку дійсно можуть відігравати головну роль у соціально-економічному розвитку, однак дискримінація цієї вікової групи не максимізує потенціал таких людей як на платній, так і на добровільній основі, та відмовляє їм у можливості відігравати значну роль у соціально-культурному житті суспільства [8].

Старість може стати благополучним i навіть щасливим періодом життя, але для цього до неї потрібно відповідним чином підготуватися. Багато сучасних дослідників вважають, що десятиліття перед виходом на пенсію є найбільш сприятливим часом для адаптації до старості. Саме в цей період треба спонукати i підтримувати самовиховні тенденції у людей, яким виповнилось 50 років, зацікавлюючи їх підготовкою до нових життєвих ситуацій. На думку Д.Ф. Чеботарьова, у профілактиці старіння великого значення набуває спеціальна підготовка до переходу на віковий пенсійний рубіж, до зміни або припинення трудової, професійної діяльності. Психологічна, фізична і трудова підготовка до переходу на пенсію та до старості має, на думку вченого, проводитися не менше, ніж за два-три роки до припинення трудової діяльності [9].

Передпенсійна підготовка може допомогти більш швидкому досягненню активного старіння. Активне старіння, за визначенням ВО3, $є$ процесом оптимізації можливостей для зміцнення здоров'я, соціальної участі та безпеки, для того, щоб поліпшити якість життя літніх людей. Таке старіння розуміється як позитивна і адаптивна відповідь на трансформацію особистого статусу літньої людини. Процес адаптації людини чи не найбільшою мірою залежить від внутрішньої установки самої літньої людини, ii налаштованості на майбутне, особистісного рівня взаємодії 3 іншими людьми, іï мотиваційної сфери, потреб, самооцінки та інших особистісних факторів. Тому так важливо сформувати внутрішню готовність літньої людини до виходу на пенсію.

Нагадаємо, що більшість експертів виділяють три основні напрями реалізації політики активного старіння: 1) зайнятість у літньому віці (повна або часткова); 2) участь літніх людей у житті суспільства (частіше через волонтерство); 3) незалежність (автономія) літніх людей [8].

Вирішення проблем літніх людей у сфері захисту їх прав, підтримки, залучення до активної громадської діяльності, використання їх досвіду та професійних знань матиме значний зиск як для громади, так і для держави в цілому. Так, люди літнього віку це найбільш активна частина населення у будь-яких реформах і політичних зрушеннях на відміну від середнього віку, більш дисципліновані споживачі послуг, активні формувачі громадської думки, основа стабільності держави. Тому важливо забезпечити способи ефективної та швидкої адаптації людей літнього віку до нових умов життєдіяльності після виходу на пенсію. Такими шляхами можуть бути: різні форми неформальної освіти, дозвіллєві об'єднання, соціальний туризм, волонтерська діяльність.

Одним 3 ефективних шляхів соціальної адаптації після виходу на пенсію $\epsilon$ неформальна освіта людей літнього віку, так як вона сприяе створенню умов для опору інволюційним процесам старіння, збереженню активної життєвої позиції, особистісному розвитку; створює умови для спілкування; допомагає адаптуватися в новій ситуації, здобувати реальні можливості та вміння впливати на ці зміни, бути мобільними й гнучким. Досить ефективною формою неформальної освіти людей літнього віку є 


\section{Питання психології}

університети третього віку, які досить активно набувають популярності в Україні.

Участь літніх людей у різних формах неформальної освіти сприяє більш швидкій адаптації до змінених умов життєдіяльності, до умов інформатизованого суспільства, виробляє впевненість у собі, задовольняє потребу у саморозвитку. Ще один шлях активної інтеграції літніх людей у суспільні процеси $\epsilon$ залучення до волонтерської діяльності. Люди, що вийшли на пенсію, можуть використовувати вільний час беручи участь у суспільній роботі, здійснюючи різні соціокультурні програми і проекти, приймати участь у соціально значимих акціях (перепис населення, вибори, фестивалі, акції), в тому числі і займатись волонтерською діяльністю. Волонтерство на сьогодні набуває широко розмаху і залучає різні верстви населення, які можуть надати добровільну безкоштовну поміч. Досвід, знання, інтелектуальний та духовний ресурс літніх людей може стати незамінним у різних напрямках волонтерської роботи - від консультативної до виробничої. Тому, активна участь у різноманітних недержавних громадських об'єднаннях альтернатива трудовій діяльності літніх людей. Крім того, створення самоорганізованих груп взаємодопомоги літніх людей один одному $\epsilon$ важливим ресурсом соціальної допомоги одиноким i непрацездатним.

Погоджуємось 3 думкою В. Рибалки та Е. Помиткіна, що вимогою сучасних реалій $\epsilon$ формування інноваційної геронтопсихологічної інфраструктури життя на основі інтеграції індивідуальних та інституціональних медичних, геронтологічних та геронтопсихологічних заходів в умовах індивідуального житла та спеціалізованих організацій, установ та об'єднань, що надають послуги оздоровчого i довголітнього характеру. Вони підкреслюють, щоб бути здоровою людиною і довгожителем, слід формувати сенс і мотивацію життя, чітко визначати його предметну основу, ставити реальну мету i плани, оволодівати i застосовувати результативні методи іiі досягнення, орієнтуватися у ринкових умовах виробництва і споживання необхідних для життя продуктів. Тобто слід не тільки мотивувати і «пізнавати себе», але і творчо, продуктивно самоактуалізовувати свій особистісний потенціал у досягненні результату. Ось чому самоактуалізація вважається психотерапевтичним, оздоровчим, геронтопсихологічним чинником. Особливо важливим для здоров'я та довголіття особистості $\epsilon$ формування медикопсихологічної, геронто-психологічної діяльності 3 притаманними їй мотивами, предметом, метою, методами та мотивом. I це стосується не тільки професійних психологів, але і кожної дорослої людини[10].

Постає практична проблема оволодіння кожної дорослої людини саме геронтопсихологічною діяльністю, спрямованою на гармонійне, повноцінне, духовно насичене довголіття. Особистість похилого віку досягає у своєму розвитку вершинних проявів, зокрема життєвої компетентності, інтелекту і мудрості, а також набуває здатності до генеративної діяльності як провідної, завдяки чому в неї виникає потреба у передаванні свого досвіду молодому поколінню.

Старість - останній період життя людини, який часто пов'язаний з поступовим відходом людини від участі в активному соціальному житті суспільства. Складність процесу старіння виражається різною швидкістю та ступенем розвитку різних систем організму, в результаті чого відбувається тривале збереження i навіть покращення функціонування одних систем i прискорена інволюція інших. Психічна старість і фізична слабкість - це не одне і те ж. Ніщо так не впливає на психічне життя людини, як усвідомлення того, що вона виключена $з$ суспільного життя. Все, що раніше здавалося головним і необхідним, у старості може втратити сенс. Досвід старіння і старості має свої психологічні особливості, індивідуальні для кожної літньої людини. Щоб уникнути негативу цих переживань та інших стресових ситуацій, необхідно дбайливо зберігати стійкі звички та їх неухильне виконання, що буде вселяти 


\section{Питання психології}

людині похилого віку спокій і відчуття недоторканності буття. У літньому віці в людини виникають нові завдання розвитку, при цьому найбільш важливими психологічними завданнями $\epsilon$ : збереження узгодженості 3 власною ідентичністю i віднаходження сенсу життя. Вирішення цих та інших вікових завдань може бути здійснено за умови використання літньою людиною такого внутрішнього ресурсу, як мудрість, реалізації потреб духовно-пізнавального, творчого характеру, бажання до змін, розвитку умінь і навичок до встановлення соціальних контактів.

Висновок. Отже, віковий період осіб похилого віку розглядається як період, в якому відбувається складна внутрішня робота, формування особами похилого віку цілісної картини свого життя, що включає переоцінку цінностей та підведення підсумків минулого життя, прийняття себе у минулому та сьогоденні, як на фізичному (старіння організму) рівні, так і в психічному плані. Період осіб похилого віку визначається як кризовий, що пов'язано 3 фізіологічним старінням, змінами соціального статусу, соціальних ролей та відмовою від життєвої експансії. Успішній адаптації осіб похилого віку сприяє міжособистісне спілкування. Головне завдання цього вікового періоду пошук нової ідентичності та сенсу життя. Мінімізувати втрату престижу після виходу на пенсію можуть нові захоплення та інтереси, неформальна освіта, волонтерська діяльність, яка допоможе заповнити вільний час, або часткова зайнятість, що забезпечить додатковий дохід.

Комплексний розгляд старіння передбачає, що воно є динамічним процесом, що задається біологічними характеристиками, суспільними обставинами соціального життя та суб'єктивними характеристиками, що грунтуються на власній інтерпретації суб'єктом соціального світу та відповідній самоідентифікації. Подібний міжпредметний розгляд старіння створює підгрунтя для інтеграції та акумуляції зусиль для вивчення старості та розробки i подальшого впровадження практичних програм соціальнопсихологічної допомоги людям похилого віку.

Перспективи подальших досліджень полягають у розробці та реалізації корекційно-розвивальної програми для людей похилого віку.

\section{Список використаних джерел}

1. Березіна О. О. Індивідуально-психологічні чинники особистісного розвитку в період геронтогенезу : автореф дис. ... канд. психол. наук : 19.00 .07 / О. О. Березіна «Педагогічна та вікова психологія». - Київ, 2012. - 19 с.

2. Горецька О.В. Геронтопсихологія: навчальний посібник / О.В. Горецька. - Х.: Видавництво Іванченка I. С., 2017.-210 с.

3. Дзюба Т. М. Психологія дорослості з основами геронтопсихології: Навч. посіб. / Т. М. Дзюба, О. Г. Коваленко; за ред. В. Ф. Моргуна. - К. : Видавничий дім «Слово», 2013. - 264 с.

4. Долинська Л.В. Співак Л.М. Геронтопсихологія: Практикум. Хрестоматія. / Л. В. Долинська. К.: Каравела, 2012.-240с.

5. Ермолаева М. Практическая психология старости. / М. Ермолаева. - М: Изд-во ЭКСМОПресc, $2002-320$ c.

6. Коваленко О. Г. Міжособистісне спілкування осіб похилого віку : психологічні аспекти : монографія / О. Г. Коваленко. - К.: Інститут обдарованої дитини, 2015 - 456 с.

7. Корнієнко I. О. Основні кореляти прийняття людиною власної старості. / I. О. Корнієнко // Науковий вісник Мукачівського державного університету. Серія : Педагогіка та психологія, 2017. - Вип. 2. - C. 235-238.

8. Кухта М.П. Соціальний потенціал людей старшого віку в Україні. [монографія] / М.П. Кухта. Київ : КНУКіМ. - 2018. - 304 с.

9. Магдисюк Л. І. Програма розвитку психологічної готовності особистості до виходу на пенсію. / Л. І. Магдисюк // Актуальні проблеми практичної психології у Волинському регіоні. Луцьк : Вежа-друк, 2015. - Т. 1. Вип. - С. $-36-46$.

10. Помиткін Е.О., Рибалка В.В. Геронтопсихологія навчання особистості похилого віку: навчальний посібник. - К.: Талком, 2020.- 184 с. 


\title{
Питання психології
}

11. Jung C. Analytical Psychology: Its Theory and Practice (The Tavistock Lectures). / C. Jung // Ark Paperbacks. 1990. -242 p.

\section{References}

1. Berezina O. O. (2012 Indyvidualno-psykholohichni chynnyky osobystisnoho rozvytku v period herontohenezu [Individual psychological factors of personal development in the period of gerontogenesis] : avtoref dys. ... kand. psykhol. nauk : 19.00.07 «Pedagogichna ta vikova psihologiya». Kiïv, 19 s. (in Ukrainian).

2. Horetska O.V. (2017). Gerontopsihologiya: navchalnij posibnik [Gerontopsychology: a textbook] Vidavnictvo Ivanchenka I. S.,. Kharkiv (in Ukrainian).

3. Dzyuba T. M., Kovalenko O. G. (2013). Psykholohiia doroslosti z osnovamy herontopsykholohii: Navch. posib.; [Psychology of adulthood with the basics of gerontopsychology: Textbook. way.] za red. V. F. Morguna. K. : Vidavnichij dim «Slovo», (in Ukrainian).

4. Dolynska L.V. Spivak L.M. (2012). Gerontopsihologiya: Praktikum. Hrestomatiya. [Gerontopsychology: Workshop. Reader] K. : Karavela. 240s. (in Ukrainian).

5. Ermolaeva M. (2002). Prakticheskaya psihologiya starosti [Practical psychology of old age] M: Izdvo EKSMO-Press. 320 s. (in Russia ).

6. Kovalenko O. G. (2015) Mizhosobistisne spilkuvannya osib pohilogo viku : psihologichni aspekti : [Interpersonal communication of the elderly: psychological aspects] monografiya K.: Institut obdarovanoï ditini. (in Ukrainian).

7. Korniienko I. O. (2017). Osnovni koreliaty pryiniattia liudynoiu vlasnoi starosti [The main correlates of a person's acceptance of their own old age] Naukovyi visnyk Mukachivskoho derzhavnoho universytetu. Seriia : Pedahohika ta psykholohiia, Vyp. 2. (in Ukrainian).

8. Kukhta M.P. (2018). Sotsialnyi potentsial liudei starshoho viku v Ukraini [Social potential of older people in Ukraine] [monohrafiia] Kyiv : KNUKiM (in Ukrainian).

9. Mahdysiuk L. I. (2015). Prohrama rozvytku psykholohichnoi hotovnosti osobystosti do vykhodu na pensiiu. [The program of development of psychological readiness of the person for retirement] Aktualni problemy praktychnoi psykholohii u Volynskomu rehioni. Lutsk : Vezha-druk,- T. 1. Vyp. (in Ukrainian).

10. Pomytkin E.O., Rybalka V.V. (2020). Herontopsykholohiia navchannia osobystosti pokhyloho viku: navchalnyi posibnyk [Gerontopsychology of teaching the elderly: a textbook] K.: Talkom (in Ukrainian).

\section{Резюме}

Воронова О. кандидат психологических наук, стариий преподаватель кафедры психологии Мукачевский государственный університет

Барчий М. старший преподаватель кафедры психологии Мукачевский государственный университет

\section{ОТДЕЛЬНЫЕ СОЦИАЛЬНО-ПСИХОЛОГИЧЕСКИЕ ПРОБЛЕМЫ СТАРЕНИЯ}

В статье проанализированы взгляды отечественных и зарубежных ученых на социальнопсихологические проблемы старения. Освещень психологические особенности пожильх людей. Рассмотрены основные подходы к изучению старости и старения; проблему эйджсизма и факторы выхода на пенсию; вопросы активного старения и предпенсионной подготовки Выделены факторы, влияющие на адаптачионные процессы пожилого человека к новому качеству жизни.

Ключевье слова: старость; старение; геронтология; пожслье люди; кризис старости; сочиальная адаптация.

\author{
Summary \\ Voronova O. Candidate of Psychological Sciences, \\ senior lecturer at the Department of Psychology \\ Mukachevo State University \\ Barchii M. senior lecturer at the Department \\ of Psychology Mukachevo State University
}

INDIVIDUAL SOCIO-PSYCHOLOGICAL PROBLEMS OF AGING

Consideration of the problems of the elderly is extremely important because their solution not only determines the activity of the elderly and their position in society, but also provides opportunities for older people to adapt to new social situations and change their attitude in society. 


\section{Питання психології}

The purpose of the article - to carry out a theoretical analysis of socio-psychological problems of aging at the current stage.

Research methods. In the course of the research the theoretical analysis and generalization of scientifictheoretical and methodical sources on the problems of the psychology of old age were used.

Scientific novelty and practical significance of research results. The authors generalized the work of foreign and Ukrainian scientists on the psychological characteristics of the elderly, socio-psychological problems of adaptation of the elderly to changes in social status, new social roles, acceptance of old age, overcoming the crisis of old age. The article emphasizes that solving the problems of the elderly in the field of protection of their rights, support, involvement in active public activities, use of their experience and professional knowledge will have significant benefits for both the community and the state as a whole. Thus, the elderly are the most active part of the population in any reforms and political changes in contrast to the middle age, more disciplined consumers of services, active shapers of public opinion, the basis of state stability. Therefore, it is important to provide ways to effectively and quickly adapt older people to the new living conditions after retirement. These ways can be: various forms of non-formal education, leisure associations, social tourism, volunteering. The participation of older people in various forms of non-formal education promotes faster adaptation to changing living conditions, to the conditions of an informed society, develops self-confidence, satisfies the need for self-development. Another way to actively integrate older people into social processes is to get involved in volunteering. Retired people can use their free time by participating in community service, implementing various socio-cultural programs and projects, participating in socially significant events (census, elections, festivals, events), including volunteering.

Conclusions and prospects for further research Comprehensive consideration of aging suggests that it is a dynamic process determined by biological characteristics, social circumstances of social life and subjective characteristics based on the subject's own interpretation of the social world and selfidentification. Such an interdisciplinary consideration of aging creates the basis for the integration and accumulation of efforts to study old age and to develop and further implement practical programs of social and psychological assistance to the elderly.

Prospects for further research are: development and implementation of a correctional and developmental program for the elderly.

Key words: eld; aging; gerontology; elderly; old age crisis; social adaptation.

Автори заявляють про відсутність конфлікту інтересів.

Recelved/Поступила: 16.12.21. 